\title{
Sustainable urban greening strategies for compact cities in developing and developed economies
}

\author{
C. Y. Jim
}

Published online: 24 October 2012

(C) The Author(s) 2012. This article is published with open access at Springerlink.com

\begin{abstract}
Urban greening contributes notably to quality of life and ecosystem services in cities. Compact cities in developing and developed countries are commonly beset by greenspace deficit. Based on literature review supplemented by field studies in different cities, a sustainable urban greening strategy is proposed. Urban renewal and new developments without a greening vision could miss the opportunities to bring relief. The public and private sectors can join hands to insert plantable spaces into the urban fabric. Urban greenspaces (UGS) with good connectivity forming a green network to permeate the city constitute the hallmarks of a naturalistic design. Preservation and creation of natural areas with rich biodiversity offer a new dimension to UGS design. Greening benefits could be expressed in economic terms to complement conventional ecological-environmental emphasis. Outstanding trees could receive high-order conservation efforts, and trees in construction sites warrant enhanced protection. Tree transplanting demands an overhaul in concepts and skills. Improving roadside tree planting and maintenance offers a cost-effective way to upgrade the townscape. Ameliorating widespread soil limitations could remove a major hindrance to tree growth. Innovative ideas of development right transfer, street pedestrianization, river and canal revitalization, green roofs and green walls could mobilize hitherto underused plantable resources. Lacking appropriate institutional setup and scientific capability pose intractable bottlenecks. Innovative public policies and greening technologies are needed for sustained improvements. Amalgamating natural and social sciences in a multidisciplinary approach and reinforcing the link between science and public policies could overhaul greening.
\end{abstract}

Keywords Compact city · Ecosystem service $\cdot$ Nature deficit · Precision planning ·

Sustainable development · Urban biodiversity · Urban ecology · Urban greenspace · Urban natural area

\section{Introduction}

The creation of cities since antiquity marked the triumph of humanity over changeable and harsh nature. One of the undesirable collaterals of urban living was detachment

C. Y. $\operatorname{Jim}(\triangle)$

Department of Geography, University of Hong Kong, Pokfulam Road, Pokfulam, Hong Kong

e-mail: hragjcy@hku.hk 
from nature. When settlements were small, nature was situated nearby, allowing humans to maintain frequent contacts. As settlements grew bigger, nature was increasingly marginalized and it became scarce, distant and often neglected or degraded. Some urbanites began to miss, consciously and sublimally, the innate link with nature. They endeavored to find solace in created natural enclaves in cities (Conan 1986). Surrogates of nature were established in the form of domestic gardens. With a utilitarian bent, plants bearing edible fruits were initially domesticated and nurtured (Ferriolo 1989; Bowe 2010). The universal human preference for aesthetic objects soon triggered the adoption of ornamental plants. Trees with large and dense crowns were cultivated for shading from the hot sun and shielding from wind impact (Lawrence 1993).

Initially, gardens were principally private domains for owners who could afford the means and the leisure to create and maintain them. The nobility and the aristocracy would establish them for personal gratification and as symbols of wealth and power. Some would maintain wild or semi-wild grounds for recreational hunting. Common people had no access to such private reserves. The continued urban expansion would occlude some private greenery in the sprawling process.

The Industrial Revolution brought factories and workers into cities, together with abject poverty, low-quality housing, excessive building density, poor hygiene and health, and degraded environmental conditions. Responding to the deprivation, people flocked to the meager open and greenspaces accessible to the public, often associated with religious and public establishments and cemeteries. Governments were eventually urged to satisfy such demands by the novel institution of urban parks, which began in nineteenth century Britain (Lawrence 1988). Some private green areas were acquired by municipal governments and opened to the public. The bold innovation was soon adopted by other countries to become an obligatory and universal amenity.

The year 2010 denotes a notable watershed in human and urbanization history, with half of the 7 billion population living in cities. The growth in population and large cities in recent decades occurred mainly in less-developed areas (United Nations Population Fund 2012). Most of the million- and mega-cities (over 10 million population) are now situated in less-developed countries (National Geographic 2012). A notable proportion of cities in less-developed countries, especially those with a long development history, tend to be compact (Jenks et al. 1996; Burton 2002) with tightly-packed urban form. With most lands usurped by buildings and roads, little interstices are left for greenery, resulting in grave deficiency in public open spaces (Jim 1989, 1998a). Urban redevelopments, new urban areas and new towns were sometimes built in haste with little regard to environmental quality (Olembo and de Rham 1987; Herz et al. 2003). The need to dilute the built-up harshness with green areas could be neglected (Marcotullio 2001). Opportunities to improve environmental quality and quality of life for millions of urban residents could be grasped in the spirit of sustainable development and smart growth (Hestmark 2000; Foo 2001). With increasing concern about climate change, cities are beset by the double scourge of global warming superimposed on urban heat island effect. Urban tree planting offers a viable way to climate proof cities, especially in high-density residential precincts (Hall et al. 2012) and a contribution to carbon offset and sequestration (Escobedo et al. 2010; Strohbach and Haase 2012). Some parts of cities in developed economies share similar problems encountered in compact cities in developing economies.

The main objective of this study is to develop a comprehensive, operational and actionable strategy to overcome the physical, psychological and institutional barriers to greening compact cities mainly in developing economies and also in developed economies (hereinafter referred to as "compact developing or developed cities" or "CDDC"). 
The World Bank (2012) classifies countries in the world by income groups according to 2010 gross national income (GNI) per capita: low $\leq$ US $\$ 1,005$; lower middle US\$1,0063,975 ; upper middle US\$3,976-12,275; and high $\geq$ US\$12,276. Low-income and middleincome economies are often referred to as developing economies. The World Bank (2012) website lists the countries in each group. Hong Kong is put in the high income group, but its urban environment is one of the most compact in the world, sharing many greening limitations and environmental problems commonly found in cities in less developed countries.

Related to the primary objective, this study aims at developing practical urban greening methods based on relevant concepts as well as exemplary practices: (a) the benefits of urban greening could be maximized by revamping entrenched thinking, practices and inertia; (b) decision makers could move from the conventional to the innovative mode, and adopt an integrated and long-term approach; (c) the entire cradleto-grave spectrum of urban greening demands attention, encompassing plantable sites, planning, design, species assemblage, installation, maintenance, management, governance, and community expectations (Attorre et al. 2000; Jim and Chen 2006a); (d) notable gaps in knowledge have been identified for proposed improvement, such as the contribution to regional biodiversity and carbon sequestration (Takahashi et al. 2008), and landscape and conservation planning (Jim and Chen 2009a, b); and (e) the framework could provide hints on future research priorities to strengthen the locally-relevant knowledge base and appropriate technology, and to inform management.

\section{Methods}

This study is mainly based on literature review, supplemented by field studies in over 100 cities in 25 countries, and research and practice experience in urban forestry in Hong Kong and other south China cities. The exemplars could serve to verify or validate the applicability of the chosen urban greening approach. Where appropriate, literature is cited (175 items in total) to lend support. Learning from field studies, however, often cannot be supported by literature, but they refer mainly to good practices rather than elucidation of concepts. As the bulk of urban ecology and urban greening researches are conducted in developed cities, their examples and good practices would be selected to inform the strategy for CDDC. The more limited studies in developing cities, if appropriate, would be included in the study. Besides expounding underlying principles, the practical and actionable applications were emphasized. A multidisciplinary and transdisciplinary approach (James et al. 2009) has been adopted to encompass relevant concepts from urban biogeography, urban ecology, urban forestry, urban horticulture, urban landscape ecology, urban environmental planning, and urban soil science.

The results and discussion of the study, given in the ensuing part of the paper, are structured according to a natural progression based on three main stages in the planningmanagement stream of urban greening: (1) Applying urban ecological principles to urban greening design, greenspace geometry, urban biodiversity enrichment, and holistic assessment of urban greening benefits; (2) Protecting nature-in-city assets, involving spontaneous natural remnants, champion-caliber tree stock, tree preservation in construction sites, salvaging outstanding trees by transplanting, and timely tree care; and (3) Augmenting greening opportunities, such as planting at narrow roadsides, ameliorating soil constraints, and introducing greenery into compact areas. 


\title{
Applying urban ecological principles
}

\author{
Adopt ecological design
}

Cities have most soils sealed by buildings, roads or paving materials (Scalenghe and Marsan 2009). The spatial variations in permeable or evaporating surfaces determine the capacity of a city to admit greenery (Arnold and Gibbons 1996; James and Bound 2009). The heterogeneous urban ecosystem demands diverse conservation treatments (Band et al. 2005). Both public and private lands could contribute to the greening endeavor (Troy et al. 2007). Urban ecological principles have seldom been enlisted to optimize the configuration and ingredients of urban greening. The conventional approach is dominated by ornamental or aesthetic considerations of landscape plants. Most urban greenspaces (UGS) were designed to achieve neat geometric patterns and well-manicured parkland landscape with limited inherited or created nature. Such outdated mentality has a strong inertia to linger in both developing and developed countries.

Modern UGS could avoid excessive regimentation of ingrained mainstream landscaping by emulating nature's diversity, variability, changeability and flexibility (Henke and Sukopp 1986; Gordon 1990; Cook and Lier 1994). The naturalistic or ecological design could create UGS with more natural species composition, community assemblage, biomass structure, and spatial pattern (Cole 1986; Cook 2002). The muffled senses of people living in cities could be revitalized by diverse visual, audio, olfactory and tactile stimuli offered by natural ingredients.

Instead of making all UGS wild, which may not be practicable, a compromise could be reached between popular expectations and nature provision. A spectrum of sites with different degree of naturalness could match the local land-use and biotope pattern (Breuste and Wohlleber 1998; Löfvenhaft et al. 2002). A large site could accommodate a variety of habitats, whereas a small site could focus on one. The pre-urbanization ecosystems around a city, including the common and rare types, could be inherited or emulated. Local ecological knowledge and has to be reinforced by research to design naturalistic UGS.

\section{Optimize greenspace geometry and connectivity}

The pertinent benefits of creating spatially connected and contiguous UGS have escaped the attention of some planners in CDDC. Natural ecosystems tend to be well connected to each other, with unimpeded flow of energy, materials, organisms, propagules and genes across contiguous boundaries. UGS, however, are usually demarcated as isolated entities surrounded by rather inhospitable built-up areas (Kong et al. 2010; Tian et al. 2011). The main green sites, urban parks, are often square or rectangular plots surrounded by roads. Some large parks are penetrated, traversed or severed by roads. The harsh and alien conditions of roads and buildings form barriers to the movement of wildlife and people. They also generate spillover impingement on UGS environmental quality to reduce their capacity to support and nurture nature.

Applying the concepts of landscape ecology (Hersperger 1994; Dramstad et al. 1996; Breuste et al. 2008) and landscape ecological urbanism (Steiner 2011) could improve spatial design of UGS. They could be analyzed as three principal entities, namely patch (broad green areas), corridor (linear green areas), and matrix (surrounding built-up areas), in conjunction with the ancillary issue of edge (interface between patches or corridors with matrix). The key geometrical properties of UGS, such as location, size, shape, orientation, and distance from and connectivity with other green patches, could be molded to enhance their ecosystem services (Davey 1998; Young 2010): 
(1) Large patches or wide corridors

They provide adequate spaces to accommodate a variety of habitats and species, especially those demanding a relatively large minimum site. They also raise the ratio between site area and edge to reduce edge impacts where the UGS interfaces with incompatible or nuisance-generating land uses.

(2) Connectivity between patches or corridors

Green sites that are close to each other or contiguous can form a green network to permeate the built-up matrix. Green patches linked by green corridors or greenways (Flink and Searns 1993) form an integrated UGS system to enmesh built up areas (Flores et al. 1998; Jim and Chen 2003). Where continuity could not be achieved in developed areas, a series of small sites with short inter-site distance could provide stepping stones for humans and wildlife.

(3) Long corridors or linear green patches

They provide extended edges with the surrounding built-up matrix, so that more residents can access conveniently, preferably by walking less than $400 \mathrm{~m}$ or $10 \mathrm{~min}$ (Müller-Perband 1979; Burgess et al. 1988). For two UGS with a similar area, the linear one with a larger catchment of potential users is preferred. Well-connected UGS permit movement of wildlife (including pollinators and dispersal agents) and propagules. Intra-urban corridors connected to peri- and extra-urban natural areas could augment such biotic movements.

(4) Patches or corridors parallel to natural linear features

Patches or corridors oriented parallel to streams or coastlines could enhance urban ecological networks (Ignatieva et al. 2010). Water bodies provide an important landscape element for joint development of greenways and blueways. People's affinity to water edges can increase the UGS appeal. It also helps to restore or conserve natural waterways or canals that run through cities.

(5) High quality green site edges

The edges between green and non-green areas could enhance ecological and landscape qualities. They should preferably be soft (natural), wide, gradual and curvilinear. Thus fences or walls that create abrupt and unfriendly barriers should be avoided.

It is desirable to mingle green patches or corridors with the built-up matrix, such that UGS are situated close to people to generate a nature-in-city ambience. At the urban edge where developments interface with natural areas, tongues or wedges of peri-urban natural areas could extend into built-up areas in an interfingering pattern (Frey 2000; Caspersen and Olafsson 2010). Small remnant nature pockets embedded in built-up areas could be kept in the wild state and designated as urban natural areas (UNA) by statutory zoning. With peninsulas of nature extending into the city and islands of nature punctuating the city, the landscape, amenity, ecological and air-quality benefits could spill into the urban matrix. In landuse planning, opportunities for nature to intermix with the city should be assiduously realized (Carr and Lane 1993). Existing green sites at the urban fringe could be ecologically upgraded to enhance ecosystem services. Nature can best be preserved; if not, emulated nature (defined as a planted area with species composition and biomass structure that are similar to a comparable natural vegetation type) could be created as surrogates (Baines and Smart 1991).

A comprehensive assessment of urban ecological endowments could optimize a city-wide UGS master plan. Such plans could embrace ecological considerations and avoid domination by locational and economic factors. To usher high-quality nature into the city, green plans could make good use of ecological realities and potentials. Sites of high ecological 
value regardless of size could be protected. In particular, small pockets of biodiversity hotspots, unique habitats, remnant native vegetation, or heritage trees, could be captured in an embracing conservation package. Pristine or minimally disturbed ecosystems offer outstanding candidates, and disturbed sites could be evaluated for recuperative potential with or without human assistance. In neighborhoods suffering from nature deficit, suitable localities could be identified for creation of natural pockets.

\section{Enrich greenspace biodiversity}

Habitat diversity could be enhanced to raise biodiversity in UGS design (Alvey 2006). For new green sites, the manicured horticultural design could be complemented by the naturalisticecological approach (Henke and Sukopp 1986). Based on the hemeroby concept (Jalas 1955; Sukopp 1972), urban habitats range from natural, to emulated or created natural, semi-natural or ruderal, and entirely artificial. Some UGS in CDDC cluster at the artificial end of the spectrum, reflecting the inertia of traditional landscape design (Qureshi and Breuste 2010). To redress the bias, new or revamped UGS could admit more natural elements. Nature-oriented designs are often less expensive to build, and largely self-sustaining with minimum maintenance needs to reduce recurrent upkeeping costs. They meet the demand for natural areas within and near cities (Johnston 1990; Tzoulas and James 2010) with features that over-designed and expensive urban parks fail to deliver (Thompson 2002).

Biodiversity in UGS could be enhanced especially with native species representative of the regional flora (Smale and Gardner 1999). For relatively large sites (e.g. $>5,000 \mathrm{~m}^{2}$ ), not less than $25 \%$ of the area could be earmarked for naturalistic greening. An ecological survey could identify existing natural habitats for incorporation into the naturalistic design. Species enrichment could be incorporated into the refurbishment scheme. Different sites could serve different ecological functions to depart from the common visualornamental bias. For large sites, the ecological-park design could include a mosaic of representative habitats.

Using natives in urban greening is often hampered by a knowledge gap. The landscape profession and industry often have limited understanding or experience with indigenous species. They tend to adhere to a standard palette of common horticultural species for a given climatic zone, resulting in stereotype landscape designs and species assemblages with a disproportionate amount of exotic species. Local botanical-ecological research could be developed to identify, test and extend the use of indigenous plants in UGS. Botanic gardens with research facilities and orientation could play a key role in filling the knowledge gap (Maunder et al. 2001a, b; Dosmann 2006). The research findings could be applied to nurture a modern horticultural-nursery industry to produce native planting materials, and a landscape profession to promote their use.

Advocating natives should not exclude exotics. Cities are characterized by a diverse range of site conditions, far more than its countryside, which can accommodate a surprisingly varied urban flora. The capacity of UGS to support a wide assortment of species could be filled by a complement of natives and exotics. Natural sites could mainly hold natives, whereas semi-natural and artificial sites could accommodate both. A plant introduction office could develop a strategy and an action plan to screen systematically worthwhile exotic species from other places, and promote suitable ones to the landscape industry. This orderly importation could replace the random introduction, legally or illegally, of exotic plants by companies or individuals. Unregulated activities operating outside the quarantine regime should be controlled to avoid phytosanitation problems and inadvertent transfer of pest organisms and instant pathogens. 
Evaluate holistic benefits of greenspace

In planning and designing UGS, there is a tendency to focus on site area or green-area per capita at the expense of high-level benefits such as ecosystem services. The narrow outlook could discourage adoption of the ecological design. The appraisal of achievement in urban greening and benefits to the community could encompass the multiple and less tangible ecosystem services, such as improvement in air quality, enhancement of stormwater quality, and suppression of the urban heat island effect. A holistic assessment could gage the wide spectrum of ecological functions. Key attributes such as species richness, species diversity index, native-exotic ratio, remnant natural component, and fidelity to local or regional natural habitats, could be rated (Jim and Chen 2009c). Other factors that contribute to the ecological-environmental well-being of the city could enter the equation, such as biomass structure, vegetation coverage, planting density, vegetation height, leaf area index, open soil and evaporative surface, and soil connected to natural ground.

Cities with different natural history, development mode, disturbance regime, nature conservation performance, and UGS provision demand different assessment methods. Local urban-ecological research could equip the assessment scheme and judge the quality of UGS plans. A small site with high scores may bring more ecosystem services than a large site with low scores. The importance of natural pocket parks in compact city areas could be stressed (Nordh et al. 2009). Selected criteria could be emphasized to guide and fulfill certain ecological-planning objectives. Individual sites could set specific targets, such as the minimum species richness and leaf area index. Such a precision UGS planning methodology could bring a renaissance to landscape design with sustainable benefits to urban ecology and residents.

Cost-benefit analysis could enhance understanding of urban greening benefits (Dochinger 1980; Nowak and Dwyer 2000). As people are more amenable to monetary than ecological values, the benefits and amenities could be expressed in dollars. As nature-in-city is not a marketable commodity, indirect methods permit objective-scientific valuation (Chen and Jim 2008). Two strands of methods have been applied to the economic assessment of urban greening. The contingent valuation method explores citizens' willingness-to-pay to use UGS, to prevent UGS loss (Jim and Chen 2006b; Lo and Jim 2012), or to preserve urban biodiversity (Chen and Jim 2010). The hedonic pricing method analyzes the home buying behavior by isolating the proportion of the property transaction price attributed to urban greening and other natural areas (Garrod and Willis 1994; Jim and Chen 2006c, 2007). The results could estimate the monetary worth of urban green areas, which could be compared with establishment and maintenance costs (Jim and Chen 2009d). The dollar values assigned to UGS could justify the allocation of public funds for urban greening, and help to compete for resources in times of budgetary constraints. In applying the monetary valuation methods, the problems and challenges in methodology and hence the results should be fully acknowledged (Carson et al. 2001; Bateman et al. 2002; Malpezzi 2003).

\section{Protecting nature-in-city assets}

Preserve and nurture spontaneous nature

Existing natural areas of high ecological worth in CDDC are often neglected or destroyed. Especially in the course of recent rapid growth, natural areas with spontaneous flora and fauna could be annihilated. Green fields in the urban fringe or the countryside envelope are 
intruded by urban sprawl. Some islands of remnant nature in the urban matrix, especially the interstitial wilderness (Jorgensen and Tylecote 2007) and semi-natural sites with significant spontaneous components (Towne 1998; Millard 2008), could be ruined by development. Occasionally, the loss of nature is partly compensated by emulated natural areas in UGS. Preservation of natural sites within developed areas too often escapes the attention of city planners (Qureshi et al. 2010). Paradoxically, the land for new UGS have to be prepared at a high cost, often involving elimination of natural features and replacement by stereotype and simple parkland landscape with limited ecosystem benefits (Fernández-Juricic 2000; Hess and King 2002).

High-quality nature can as far as practicable be kept in development areas instead of establishing new UGS from scratch. Valuable natural remnants are often replaced by humanized greenery. Occasionally, isolated well-wooded religious sites or sacred groves are retained in built-up areas (Jim 2003a; Hong et al. 2007; Ormsby 2011). However, the natural landform, soil, water and vegetation of the preserved sites tend to be modified or partly replaced (Williams et al. 2005). Urban living has probably muffled if not distorted our value judgment of nature. Wild areas are commonly and erroneously construed as inferior or unsuitable UGS (Mazzotti and Morgenstern 1997). Nature has to exist in urbanized areas on human terms, to be simplified, sanitized, contained, tamed, regimented and manicured. Such persistent attitude has unnecessarily eliminated or degraded high-caliber natural sites. Paradoxically, in their place we create parodies of nature that incur high capital and recurrent expenditures.

Landuse zoning could be revamped to rescue nature in cities (Goldsmith 1988). Natural areas with high conservation value or are critically endangered can be proactively identified and protected by zoning and related legal instruments (Mills et al. 2009; Freeman and Bell 2011). Habitats with significant indigenous vegetation and wildlife should receive special protection (Breuste 2004). Instead of treating development land as a blank sheet, green fields could be designated as urban natural areas (UNA) with protected-area status analogous to countryside conservation areas. Natural patches and corridors could be preserved as far as possible in their present state (Henke and Sukopp 1986), for incorporation in a green network preferably connected to the city's countryside (cf. Section on Adopt Ecological Design in Urban Greening). Remnant woodlands with high biodiversity, ecological value and ecosystem services should receive special attention (Croci et al. 2008; Jim 2011a, b). Core habitats and migration corridors could be preserved in a smart-growth and spatial-planning package. Spokes, fingers or tongues of linear UNA lands extending into built-up areas create a desirable spatial pattern to maximize nature's benefits. Such greenways (Flink and Searns 1993) permit fresh air, clean water and wildlife to enter the city via natural expressways. The riparian corridor with existing woodlands that traverse a city is particularly valuable for habitat and biodiversity conservation (Pennington et al. 2010). Residential areas could have convenient access to nature and enjoyment of ecosystem services (Freeman and Bell 2011).

Where natural areas are deficient, they could be nurtured with the careful site and soil preparation and native plant species to emulate regional wooded ecosystems (Johnston 1990; Lee and Thompson 2005). Disturbed natural areas could be repaired or restored by enrichment planting and elimination of undesirable elements to foster reconstitution of natural ecosystem (Borgmann and Rodewald 2005). Parts of existing green sites could be enriched with natural ingredients in terms of species composition and biomass structure. Where the climatic zone permits, woodland as the most complex ecosystem could be established by an afforestation program (Tartaglia-Kershaw 1982; Harmer 1999). The overarching spatial planning principle is to create adjacency and interpenetration between natural and urbanized areas. The health and vigor of UNA could indicate urban livability and environmental sustainability. Cities that permit nature to thrive are likely to permit humans to thrive. 
Conserve champion quality trees

Champion quality trees, as the most outstanding remnants of nature in cities, are often advertently and inadvertently damaged. In the course of urban development, a tiny subset of trees could perform exceptionally well in tree form, stature, vigor and life span. Local residents often develop sentimental attachment to them, sometimes elevated to veneration or worship. The cream of the tree stock could be identified by six criteria: species, dimensions, structure, performance, location, and special considerations such as species rarity, special ecological value, unique habitat, unusual tree form or dimensions, connection with notable personalities or events, landmark specimen, and historical significance (Jim 1994a, b).

Champion trees are comparable to cultural heritage (antiquities and monuments) due to intimate association with the local community (Jim 2004b, 2005b, c). They denote outstanding representatives and ambassadors of nature in cities, and could be treated as the collective natural-cum-cultural heritage of the community. In many cities, they are inadequately protected against damages by natural and human causes (Jim 2003b, 2005a). The alarming losses echo the lack of understanding and appreciation of an irreplaceable community heritage. The major predisposing causes for losses are related to construction and trenching-roadwork activities, with some succumbing to age and health problems. Most cities have inherited only a small number of champion trees as ecological gems. The fast development and renewal of some CDDC have continued to damage this precious endowment. They deserve intensive monitoring, care and statutory protection.

A dedicated urban tree ordinance (Jim and Liu 2000; Jim 2002) could be enacted, with a section covering special measures to guard them against harm. A systematic champion tree survey can establish a scientific database (Council of Tree and Landscape Appraisers 2000) to deepen appreciation of tree heritage value and reinforce tree management. They also constitute a benchmark to determine the level of compensation and penalty in case of damage (Jim 2004a). The data can allow development of a monetary valuation of the prized trees (Jim 2006). A champion tree register should cover developed lands and sites earmarked for development, and as an integral part of the tree ordinance (Randall and Clepper 1977). Professional tree-care guidelines and tree workers at the highest international standard could ensure high-grade maintenance.

Cities could learn from the best practices to improve the protection regime. The outstanding trees could be conserved collaterally with their sites and environs. Heritage trees would have witnessed the vicissitudes of their surroundings for decades if not centuries. Nearby urban fabrics of historical significance could have lingered with their natural partners, to deserve co-conservation and co-management with the elite trees. The overall townscape, including the housing styles and the high-quality vegetation cover in private lots, qualify as a holistic conservation entity.

The conservation area concept that protects countryside and natural habitats could cover urban sites with high-caliber trees. A sizeable area with a notable number of champion trees could be designated as tree conservation areas. Roads lined with champion trees could be designated as tree conservation roads. Smaller sites including a special habitat such as a remnant woodland enclave, an old stone wall with hanging mature trees (Jim 1998a; Jim and Chen 2010), or old buildings with interesting spontaneous tree growth (Jim and Chen 2011), could be designated as tree conservation sites. The tree conservation strategy should take into account the past, present and future considerations in the spirit of transgenerational urban forestry and arboriculture (Jim 2005c).

Tree conservation should pay special attention to protecting present and future growth spaces. Besides the above-ground expansion space, the often neglected subterranean rooting 
room should be guarded against intrusion and degradation. If a particularly valuable tree is encountered and the site conditions permit, a three-dimensional tree protection zone (TPZ) could be delineated ( $\mathrm{Jim}$ 1988). For champion trees that have not attained their potential dimensions, the TPZ should allow for future growth. In the below-ground environment, a sufficient soil mass not less than $1 \mathrm{~m}$ deep and as wide as the final crown spread should be provided to permit future root expansion. No excavation should be permitted in the TPZ. For trees cloistered by adjacent developments and do not have sufficient rooms to demarcate the $\mathrm{TPZ}$, any future changes should prevent deterioration of tree growth conditions. Ameliorative measures could be applied to improve conditions for tree growth. Adjoining redevelopments should include setback (a town planning term meaning the required distance separating a building or structure from a property line) to enlarge the TPZ. Champion trees should be recorded on statutory zoning plans. Instead of denoting the tree location only, the boundary of the TPZ should be shown on the map like cultural relicts. The explanatory notes of the zoning plan could provide details on tree species, dimensions, protection justifications, and precautions to prevent damages. Developers and professionals involved in the development process could interpret the zoning plans and participate actively in their protection.

Protecting trees in construction sites

Many CDDC are redeveloped and expanded at a fast rate, incurring many incongruous encounters between trees and development (Bowers 1999), which often conflict with existing trees (Watson and Neely 1995). The lack of effective statutory measures could fail to protect outstanding trees in construction sites. Trees prescribed for in situ preservation could be badly mistreated, resulting in degradation, injuries or death. The special skills required to protect trees in construction sites are often lacking. Preserved trees could be felled or killed due to improper treatment and poor protective measures. Effective measures could salvage more high-quality trees associated with construction.

Tree preservation in construction sites requires detailed planning with regard to building footprint and foundation spread, access roads and ancillary paved areas (Jim 1988). The development process could match modern environmental protection practices. Instead of treating the development site as a blank sheet, an ecological site survey should identify trees or ecological habitats deserving preservation. A precision planning takes into account realworld site conditions, and treats outstanding natural features as assets rather than liabilities. Instead of development plans that are apathetic and antagonistic to nature, they should be sympathetic and synergistic. The size, shape, orientation and location of buildings and roads could be adjusted to match conservation needs. The inputs of landscape professionals should be solicited at the early rather than the late stage of the development stream.

Tree-protection practices in construction sites in CDDC have room for improvement (Morell 1992). Besides low standard, tree protection is beset by inadequate supervision of site workers. The half-hearted efforts and cavalier attitudes suggest lack of commitment. Site crews often take calculated risks to expedite construction work at the expense of trees. Clearly written guidelines should be prepared and enforced (Matheny and Clark 1998), to be supplemented by training in relevant concepts, skills and regulations. The knowledge transfer should permeate all levels from the management to the professionals, technicians and workers. Developers and construction companies should learn tree-survey and timely preventive and precautionary measures at the earliest opportunity (Ames and Dewald 2003). The engineers and architects at the frontline of the construction project should take care of the quality control of tree-related tasks. As an incentive to tree preservation, that high quality trees could augment property value (Anderson and Cordell 1988) should be emphatically brought home. 
A common weak link is the poor and inconsistent quality of tree survey reports (TSR), upon which decisions on trees are made. A substandard or inaccurate TSR could mislead and muddle. A guideline could explain specific TSR requirements with the help of a sample report (American Society of Consulting Arborists 2004; British Standards Institution 2012). A professional TSR should cover information on individual trees, including location, species, dimensions (tree height, trunk diameter and crown spread), structural integrity, health, performance, habitat condition, tree defects and disorders, special features, future growth prognosis, and color photographs of the whole tree as well as its notable parts and environs. It should provide specific recommendations and justifications for retention, transplanting and felling. Every effort should be taken to minimize transplanting and felling. The key task of TSR preparation should only be entrusted to a tree specialist.

Transplant trees as the last resort

High-quality trees affected by development are often indiscriminately recommended for transplanting rather than in situ preservation. Developers are tempted to eliminate obstacles to construction activities and the development. Application for transplanting is often attempted to transfer the trees to locations in or outside the subject site. The option of transplanting outstanding trees, especially large specimens, should be taken as the last resort. Moving a large tree often weakens and disfigures it, substantially reducing its landscape value and useful life span, and negating the very purpose of keeping it (Jim 1995; Watson and Himelick 1997; Harris 2004). Compensatory planting in lieu of preserving trees should be scrutinized with caution, for new planting could hardly make up for magnificent old trees.

To transplant a large tree, a tree specialist and a structural engineer should team up to execute the complex task. It should be prepared in advance to reduce the transplant shock and to increase the chance of success. The indispensable phased root pruning stage is too commonly omitted. Ideally, a tree should be transplanted with all its roots in the undisturbed soil envelope. During the move, the soil in the rootball must not be disturbed or deformed to avoid injuring the roots. In practice, moving all roots is not possible, because the rootball will be too large and heavy. Recent tree root research suggests moving a manageable amount of roots, so that the rootball could be lifted and transported.

The recommended minimum rootball, with width ten times the trunk diameter at breast height (DBH) (Watson and Himelick 2005) and depth of 1-2 m, is dependent on tree size. Adhering to the prescribed rootball size entails losing over $80 \%$ of a tree's roots, hence roots have to be cut in preparing the rootball. The drastic root loss imposes extreme stresses on tree functions and health (Jim 1995). Some trees that cannot tolerate may perish; others may struggle to survive in a feeble state. It takes years for an injured tree to heal, and full recovery may not be feasible. To reduce massive root amputation in rootball preparation, roots should be pruned in phases with intervening recuperative periods. For a large tree, root pruning demands four phases each separated by at least 6 months, requiring transplant work to start 2 years in advance. Due to ignorance of transplanting concepts and practices, this advanced planning horizon is seldom realized. The receiving site should be carefully chosen and prepared to permit healthy growth of the new migrant. It should provide adequate room for future expansion. The soil, drainage and microclimatic (wind and solar exposure, temperature and humidity) conditions should match the source site. The precision arboriculture practice (Powell 1992; Starbuck 2007; ArborMaster 2012) should be based firmly on careful site and tree assessment. 
Upgrade tree-care quality and timeliness

The low-quality and delayed tree care cannot nurture the next generation of healthy and robust trees. Arboriculture and urban forestry in some cities are constrained by weak links and gaps in knowledge and applications. Trees commonly suffer from inadequate and unprofessional maintenance (Watson and Himelick 1997; Harris 2004). Newly planted trees may receive more attention mainly due to the post-planting maintenance and warranty contract of 1 to 2 years. Long-term and preventive tree care is often inadequate. Mature trees including champion specimens, could be neglected. Most urban trees encounter more growth problems than those in the countryside, requiring more care which is often not provided. The urban tree management package could focus more on tree care to treat it as a long-term cradle-to-grave enterprise.

Trees in CDDC are often inflicted by chronic problems originated from poor-quality planting materials. They relate to poor nursery practice and inability to maintain a high and consistent standard. The common weaknesses include lack of vigor, crossed branches, v-crotch, unbalanced crown, crooked or curved trunk, multiple stems, wounds, decays, sparse foliage, kinked or girdling roots, injured roots, pest and disease infestation, and tiny rootball (Jim 1997b). Such problems existing at the seedling and sapling stages would in time develop into long-term liabilities and potential hazards of mature trees. The problems begin in the nurseries, associated with the lack of selection of seeds and seedlings to eliminate weaklings, and little corrective pruning and branch training. Nursery production methods demand an overhaul to meet vigorous planting-material specifications. Substandard planting materials should be resolutely rejected.

Poor tree management in some CDDC is related to inadequate and infrequent tree inspection and the lack of a comprehensive assessment method. The visual tree assessment (VTA) based on the body language of trees (Mattheck and Breloer 1994) should be supplemented by instrumental tests, and conducted by qualified specialists in good time. The VTA results should inform preventive or pre-emptive maintenance to reduce the future need for care. The problems could be classified by the degree of exigency and given timely treatments without procrastination.

The tree-care staff should receive training commensurate with staff grade and job responsibilities. Technical skills in horticulture and arboriculture demand formal training coupled with on-the-job practices. The tree-care team should be led by an urban forester who should be a tree specialist educated to the degree level or above. Continuing professional development should be mandatory to acquire the latest concepts and practices. Establishment an urban forester post with an attractive compensation package could strengthen leadership and quality in the tree team. Overseas secondment and professional visits could encourage exchange of ideas and best practices based on first-hand experience.

Some CDDC lack urban forestry knowledge especially on native species, which hinders urban greening work. Research conducted in developed countries may not be directly transferable to the less-developed world. The shortage of relevant basic and applied research calls for strengthening of local knowledge repertoire and capability. Networking of scientists and practitioners in an urban forestry league, grouped by geographical regions, could facilitate sharing of research resources and findings.

\section{Augmenting greening opportunities}

Hone planting techniques at narrow roadsides

Roadside trees are the most cost-effective and conspicuous way to enhance the cityscape. Conventional planting techniques can hardly raise the quantity and quality of street trees in 
CDDC. The roadside space above and below the ground is commonly inadequate or unsuitable for trees (de la Chevallerie 1986; Jim 1997a, b). In old districts, buildings usually have $100 \%$ site coverage with little setback from the lot frontage for trees. Sidewalks are usually too narrow or too heavily used to afford tree planting (Kuhns et al. 1985; Evans et al. 1990). In this context, the old districts recommended for enhanced greening are those with little or no cultural, historical, heritage or conservation value, and have been designated or approved for urban redevelopment. In high-density areas, the footpaths are usually covered by awnings or arcades. In medium- and low-density areas, the limited setbacks are often cordoned off by walls and paved with concrete for parking or other non-green uses.

City planning departments often prescribe the width of roadside planting strips to be the greatest width feasible given the required minimum paved width of the sidewalk established under transport regulations (e.g. New York City 2012). Some cities maintain lists of recommended street tree species of different final dimensions based on the width of the planting strip (e.g. Portland City 2012). A proposed minimum setback of $3 \mathrm{~m}$ along roadsides could create a planting strip to accommodate small to medium trees in densely-packed areas (Jim 1997a, 1999). Wider setback, where site conditions permit, can provide space for larger trees. The required land could be derived from redevelopment sites or conversion of vehicular carriageway. Building awning and advertisement signs should not intrude into the tree strip. The underground space should be reserved for tree roots, and buried utilities and other subsurface installation should not infringe. The unimpeded soil in the strip should be $1 \mathrm{~m}$ deep to accommodate tree-root requirements (Perry 1982; Day et al. 2010). Where space is limited, a narrower roadside planting strip of preferably $1 \mathrm{~m}$ wide could allow the growth of shrubs and herbs.

To encourage setback, incentives such as the transfer of development right of the setback strip to the remainder of the plot or bonus plot ratio could be offered. Wider setback should be targeted to accommodate large trees for notable landscape improvement (Jim 1999). For setback $>3 \mathrm{~m}$, a road-median planting strip could be provided in addition to the lot-frontage one. Hard landscape could accompany the new green strips improve significantly the roadside pedestrian environment. A comprehensive and integrated approach to introduce greenery into old city areas could be instituted.

\section{Ameliorate pervasive urban soil constraints}

Urban soils especially at roadsides are often not conducive to healthy tree growth, yet they are seldom improved in greening programs (Bartens et al. 2010). The main physical problems are shallow soil layer, obstruction by rocks, building foundations and utility control boxes, excessive amount of stones and sand, poor soil structure, soil compaction, and sealing of the soil surface by concrete or asphalt (Jim 1993, 1998a, b; Perry 1994). The soil environment has poor aeration, limited moisture holding capacity and impeded drainage (Morgenroth and Buchan 2009). The poor chemical soils properties impose additional constraints, notably contamination by construction rubbles with calcareous concrete and cement fragments that raise the soil reaction to the harmful alkaline range. Urban soils are the sink for pollutants brought by run-on water, rainfall and gravity settlement from the atmosphere (Craul 1980; Jim 1998c). The shortage of available nutrients especially the essential nitrogen and phosphorus commonly dampens tree growth (Jim 1998d, e).

The poor urban soil quality is often neglected in tree programs (Bullock and Gregory 1991; Craul 1992). The common misconception is that any soil can grow trees, and soil deficiencies can be easily rectified. Thus trees are often planted in poor site soil without improvement. Inferior soil trapped in the urban landscape after construction is difficult to 
ameliorate or replace. Such poor soil cannot nurture healthy trees, resulting in heavy management liabilities. As soil materials are relatively inexpensive, poor site soils should be replaced by a good soil mix down to about $1 \mathrm{~m}$ deep before trees are planted (Lindsey and Bassuk 1991). Localized improvement in a tree pit cannot help. At roadsides, a continuous soil corridor could be installed, with a reinforced concrete slab cover to return walkable surface to pedestrians. Roots along the corridor can share the soil and spread out to enhance growth and anchorage.

\section{Embrace innovative greening ideas and sites}

Urban-greening planners and managers could think out-of-the-box to find innovative opportunities and solutions. In old urban areas, redevelopment offer chances to increase plantable spaces within and at the frontage of building sites. In densely-packed neighborhoods with inadequate UGS provision, brownfield sites could become UGS to bring relief (Doick et al. 2009). Brownfield sites colonized spontaneously by vegetation could be conserved (Schadek et al. 2009). The development right of the enlisted land parcel could be transferred to new development areas where UGS provision is well-planned and sufficient. Such shifting of development right, applied systematically, could gradually improve the landscape and environmental qualities of old districts. Enabling incentives and planning laws could encourage developers to participate in landuse restructuring.

Some side streets in CDDC are hardly used by vehicles, which could be diverted to nearby roads to permit pedestrianization and greening. Simple planting with beautiful flowering trees could be preferred by residents than expensive hard landscape. However, emergency vehicle access often restricts planting opportunities in narrow pedestrianized streets. Thus planting is limited on the edge and on one side only; where the streets are too narrow, planting is not permitted. Planting small trees that can be run over by emergency vehicles offer a possible solution. As emergency vehicle accesses are seldom used, most of the sites could be covered by greenery instead of hard paving, with the proviso that the vegetation could be sacrificed if it is necessary. It is relatively easy and fast to replace the lost small trees.

The amenity value of old river courses or canals is often neglected in old districts. Some may become contaminated or clogged, and others may be covered by a deck. They could be restored and revitalized by cleaning the water course in conjunction with greening of the banks to create blueways bordered by greenways (Bae 2011). As people have strong affinity for water, particularly the land-water interface, such transformed amenity strips could serve as linear urban parks (Van Der Windt and Swart 2008). The water surfaces together with vegetation could lower air temperature and ameliorate the urban heat island effect. The waterfront area facing the harbor in some cities could similarly be upgraded to create a green promenade with attendant benefits.

Many city areas have on-street car parking at the curbside. The area between two contiguous parking spaces could accommodate an at-grade (at the same level as the road surface) tree pit with its soil protected from vehicular compaction by a metal grille. Alternatively, a raised planter could be installed. Streets that are otherwise treeless could be greened.

Some cities have tramways or railways laid along roads often at the median position. The rather extensive strips are usually paved with concrete, asphalt or stones. They could be replaced with soil and herbaceous vegetation. Besides turfgrass, native flowering herbs could significantly improve the streetscape. Where the tracks are shared with vehicular traffic, a porous paving system could carry the traffic and permit some herb growth. Many European cities have extensive green tracks, adding a new dimension to urban greening. CDDC could modify the method to suit local conditions. 
In the pervasive compact developments, plantable space at the ground level is limited. The largely bare flat roof tops could be enlisted for green roof installation. Where the loading capacity is limited, the light-weight extensive green roof could be adopted. Where the roof slab is strong, the intensive green roof with small trees and shrubs provide high-quality sky gardens (Jim 2008; Tian and Jim 2011). Green roofs offer recreational areas to supplement the ground-level UGS stock. Moreover, they provide environmental and ecological benefits such as temperature cooling, air pollutant removal, noise reduction, storm water discharge reduction and water quality improvement, and wildlife habitats (Dunnett and Kingsbury 2004; Jim and Tsang 2011; Jim and Peng 2012).

Numerous building facades and walls offer vertical greening opportunities that have hardly been realized in CDDC (Alexandri and Jones 2008). Appropriate technology and materials could be evaluated to suit local conditions (Jim and He 2011). Native species, preferably flowering climbers, could be tested by field experiments. Green walls bring benefits similar to green roofs, plus the more prominent visual amenity to invigorate the cityscape.

\section{Conclusion}

Urban greening has a long tradition in many cities, but in some CDDC it is beset by multiple constraints and inertia. Fast urban expansion has strained the quality of the environment and urban life. Urban greening could be degraded and neglected in the hasty rush towards economic growth. Development and greening could join hand to contribute to sustainable development and smart growth (Gatrell and Jensen 2002). An overhauled urban planning regime could treat greening as an indispensable infrastructure, rather than dispensable options to fill residual niches. The naturalistic or ecological approach could transform UGS design. Aligning the spatial pattern of UGS with nature in a well-connected network could significantly improve their benefits and functions. They bring bonuses such as reduction in the capital and recurrent costs of greening programs, and higher level of user satisfaction.

The technical solutions are not difficult to apply, and they could be adjusted and refined to suit the local environment. Relevant urban forestry and arboricultural concepts and skills could be acquired by education and training. The quality of tree professionals and workers, and associated equipment, are amenable to improvement. The more difficult hurdles lie in the institutional bottlenecks and psychological barriers. Modifying the administrative and statutory regimes could facilitate development of enabling government policies in landscape and conservation planning (Gordon et al. 2009; Hill et al. 2010). Enacting a comprehensive urban greening ordinance can provide impetus and a structured framework to greening work. Encouraging public participation and engagement could make urban greening relevant and welcome by citizens.

The persistent adherence to the urbanized strand of environmental determinism, that compact cities cannot become meritorious green cities, has stifled initiatives and enthusiasm. The general neglect of tree care could be rectified by the long-term vision of transgenerational urban forestry and arboriculture. The inertia of sticking to the old-fashioned, anachronistic and often erroneous techniques presents another hindrance. Cities could be compact as well as green, with meticulous attention to every aspect of the urban greening complex. The overriding concern of quality has to permeate all greening plans and tasks.

The knowledge gap in urban greening, with particular reference to the use and care of native species in urban horticultural applications, needs to be filled by research in conjunction with knowledge exchange and transfer. It highlights inadequacies in research infrastructure, scientists, funding, and an enabling research environment. The principal determinant of a successful urban greening program is the successful synergy of researchers, practitioners, and decision makers. If they could excel in unison, urban greening could be facilitated and upgraded. 
A major difference between a developing and developed economy is that the former often finds a balance between development and nature, whereas the latter tends to tilt towards development. A developed economy is more likely to stress research and integration of findings into policies and practices (Mazzotti and Morgenstern 1997). A hallmark of a sustainable city is the embodiment of sufficient natural ingredients in a permeating configuration into the built-up matrix. The basic precept is to optimize the factors to include healthy trees into the town plan (Petit et al. 1995), which is highly feasible. The major obstacles lie in the administrative, political and policy realms (Duvernoy 1995; Bowers 1999). We need an innovative spirit and vision to take urban greening ideas and ideals to fruition in CDDC.

Acknowledgments The research grant support kindly provided by the Dr Stanley Ho Alumni Challenge Fund and the Government Matching Fund is gratefully appreciated.

Open Access This article is distributed under the terms of the Creative Commons Attribution License which permits any use, distribution, and reproduction in any medium, provided the original author(s) and the source are credited.

\section{References}

Alexandri E, Jones P (2008) Temperature decreases in an urban canyon due to green walls and green roofs in diverse climates. Build Environ 43:480-493

Alvey AA (2006) Promoting and preserving biodiversity in the urban forest. Urban For Urban Green 5:195201

American Society of Consulting Arborists (2004) A consultant's guide to writing effective reports. Rockville, $\mathrm{MD}$

Ames B, Dewald S (2003) Working proactively with developers to preserve urban trees. Cities 20:95-100

Anderson LM, Cordell HK (1988) Influence of trees on residential property in values in Athens, Georgia (USA): a survey based on actual sales prices. Landsc Urban Plan 15:153-164

ArborMaster (2012) ArborMaster level I precision felling, chain saw handling and maintenance. International Society of Arboriculture, Asheville

Arnold CL Jr, Gibbons CJ (1996) Impervious surface coverage: the emergence of a key environmental indicator. J Am Plan Assoc 62:243-258

Attorre F, Bruno M, Francesconi F, Valenti R, Bruno F (2000) Landscape changes of Rome through tree-lined roads. Landsc Urban Plan 49:115-128

Bae H (2011) Urban stream restoration in Korea: design consideration and residents" willingness to pay. Urban For Urban Green 10:119-126

Baines C, Smart J (1991) A guide to habitat creation. London Ecology Unit, London

Band LE, Cadenasso ML, Grimmond CS, Grove JM, Pickett STA (2005) Heterogeneity in urban ecosystems: patterns and process. In: Lovett GM, Turner MG, Jones CG, Weathers KC (eds) Ecosystems function in heterogeneous landscapes. Springer, Berlin, pp 257-278

Bartens J, Wiseman PE, Smiley ET (2010) Stability of landscape trees in engineered and conventional urban soil mixes. Urban For Urban Green 9:333-338

Bateman IJ, Carson RT, Day B, Hanemann MW, Hanley N, Hett T, Lee MJ, Loomes G, Mourato S, Özdemiroglu E, Pearce DW (2002) Economic valuation with stated preference techniques: A manual. Edward Elgar, Cheltenham

Borgmann KL, Rodewald AD (2005) Forest restoration in urbanizing landscapes: interactions between landuses and exotic shrubs. Restor Ecol 13:334-340

Bowe P (2010) The evolution of the ancient Greek garden. Stud Hist Gard Des Landsc Int Q 30:208-223

Bowers J (1999) Policy instruments for the conservation of remnant vegetation on private land. Biol Conserv 87:327-339

Breuste H (2004) Decision making, planning and design for the conservation of indigenous vegetation within urban development. Landsc Urban Plan 68:439-452

Breuste H, Wohlleber S (1998) Goals and measures of nature conservation and landscape protection in urban cultural landscapes of Central Europe - examples from Leipzig. In: Breuste J, Feldmann H, Uhlmann O (eds) Urban ecology. Springer, Berlin, pp 676-682 
Breuste J, Niemelä J, Snep RH (2008) Applying landscape ecological principles in urban environments. Landsc Ecol 23:1139-1142

British Standards Institution (2012) BS 5837:2012 trees in relation to design, demolition and construction: Recommendations. BSI, London

Bullock P, Gregory PJ (eds) (1991) Soils in the urban environment. Blackwell, Oxford

Burgess J, Harrison CM, Limb M (1988) People, parks and the urban green: a study of popular meanings and value for open spaces in the city. Urban Stud 25:455-473

Burton E (2002) Measuring urban compactness in UK towns and cities. Environ Plan B Plan Des 29:219-250

Carr S, Lane A (1993) Practical conservation urban habitats. Open University and Nature Conservancy Council. Hodder and Stoughton, London

Carson RT, Flores NE, Meade NF (2001) Contingent valuation: controversies and evidence. Environ Resour Econ 18:173-210

Caspersen OH, Olafsson AS (2010) Recreational mapping and planning for enlargement of the green structure in Greater Copenhagen. Urban For Urban Green 9:101-112

Chen WY, Jim CY (2008) Evaluation and valuation of the diversified ecosystem services provided by urban forests. In: Carreiro MM, Song YC, Wu JG (eds) Ecology and management of urban forests: An international perspective. Springer, New York, pp 53-83

Chen WY, Jim CY (2010) Resident motivations and willingness-to-pay for urban biodiversity conservation in Guangzhou (China). Environ Manag 45:1052-1064

Cole L (1986) Urban opportunities for a more natural approach. In: Bradshaw AD, Goode DA, Thorp EHP (eds) Ecology and design in landscape. Blackwell, Oxford, pp 417-431

Conan M (1986) Nature into art: gardens and landscapes in the everyday life of Ancient Rome. J Gard Hist 6:348-356

Cook E (2002) Landscape structure indices for assessing urban ecological networks. Landsc Urban Plan 58:269-280

Cook E, Lier HV (1994) Landscape planning and ecological networks: an introduction. In: Cook E, Lier HV (eds) Landscape planning and ecological network. Elsevier, Amsterdam, pp 1-4

Council of Tree and Landscape Appraisers (2000) Guide for plant appraisal, 9th edn. International Society of Arboriculture, Champaign

Craul PJ (1980) Characterization of streetside soils in Syracuse, New York. METRIA Proc 3:88-101

Craul PJ (1992) Urban soil in landscape design. John Wiley, New York

Croci S, Butet A, Georges A, Aguejdad R, Clergeau P (2008) Small urban woodlands as biodiversity conservation hot-spot: a multi-taxon approach. Landsc Ecol 23:1171-1186

Davey AG (1998) National system planning for protected areas. World Conservation Union, Gland

Day SD, Wiseman PE, Dickinson SB, Harris JR (2010) Contemporary concepts of root system architecture of urban trees. Arboricult Urban For 36:149-159

de la Chevallerie H (1986) The ecology and preservation of street trees. In: Bradshaw AD, Goode DA, Thorp EHP (eds) Ecology and design in landscape. Blackwell, Oxford, pp 383-397

Dochinger LS (1980) Interception of airborne particles by tree plantings. J Environ Qual 9:265-268

Doick KJ, Sellers G, Castan-Broto V, Silverthorne T (2009) Understanding success in the context of brownfield greening projects: the requirement for outcome evaluation in urban greenspace success assessment. Urban For Urban Green 8:163-178

Dosmann MS (2006) Research in the garden: averting the collections crisis. Bot Rev 72:207-234

Dramstad WE, Olsen JD, Forman RTT (1996) Landscape ecology principles in landscape architecture and land-use planning. Island Press, Washington, DC

Dunnett M, Kingsbury N (eds) (2004) Planting green roofs and living walls. Timber Press, Portland

Duvernoy G (1995) Keeping it green, political and administrative issues in the preservation of the urban forest. In: Bradley GA (ed) Urban forest landscapes: Integrating multidisciplinary perspectives. University of Washington Press, Seattle, pp 78-87

Escobedo F, Varela S, Zhao M, Wagner JE, Zipperer W (2010) Analyzing the efficacy of subtropical urban forests in offsetting carbon emissions form cities. Environ Sci Pol 13:362-372

Evans M, Bassuk N, Trowbridge P (1990) Sidewalk design. Landsc Architect 80:102-103

Fernández-Juricic E (2000) Avifaunal use of wooded streets in an urban landscape. Conserv Biol 14:512-521

Ferriolo MV (1989) Homer's garden. J Gard Hist 9:86-94

Flink CA, Searns RM (1993) Greenways: A guide to planning, design, and development. Island Press, Washington, DC

Flores A, Pickett STA, Zipperer WC, Pouyat RV, Pirani R (1998) Adopting a modern ecological view of the metropolitan landscape: the case of a greenspace system for the New York City region. Landsc Urban Plan 39:295-308

Foo TS (2001) Planning and design of Tampines, an award-winning high-rise, high-density township in Singapore. Cities 18:33-42

Freeman RC, Bell KP (2011) Conservation versus cluster subdivisions and implications for habitat connectivity. Landsc Urban Plan 101:30-42 
Frey HW (2000) Not green belts but green wedges: the precarious relationship between city and country. Urban Des Int 5:13-25

Garrod G, Willis K (1994) An economic estimate of the effect of a waterside location on property values. Environ Resour Econ 4:209-217

Gatrell JD, Jensen RR (2002) Growth through greening: developing and assessing alternative economic development programmes. Appl Geogr 22:331-350

Goldsmith FB (1988) Threats to woodland in an urban landscape: a case study in Greater London. Landsc Urban Plan 16:221-228

Gordon D (ed) (1990) Green cities: ecologically sound approaches to urban space. Black Rose, Montreal

Gordon A, Simondson D, White M, Moilanen A, Bekessy SA (2009) Integrating conservation planning and landuse planning in urban landscapes. Landsc Urban Plan 91:183-194

Hall JM, Handley JF, Ennos AR (2012) The potential of tree planting to climate-proof high density residential areas in Manchester, UK. Landsc Urban Plan 104:410-417

Harmer R (1999) Creating new native woodlands: Turning ideas into reality. Information Note 15, Forestry Commission, Edinburgh, UK

Harris RW (2004) Arboriculture: Integrated management of landscape trees, shrubs and vines, 4th edn. Regents/Prentice Hall, Englewood Cliffs

Henke H, Sukopp H (1986) A natural approach in cities. In: Bradshaw AD, Goode DA, Thorp EHP (eds) ecology and design in landscape. Blackwell, Oxford, pp 307-324

Hersperger AM (1994) Landscape ecology and its potential application to planning. J Plan Lit 9:14-29

Herz R, Schroeder H, Stahre P, Stal Ö, Woodward S (2003) Towards the integrated management of urban vegetation and infrastructure. Final report of COST C3 Working Group Vegetation and Urban Civil Engineering, European Union, Brussels

Hess GR, King TJ (2002) Planning open spaces for wildlife. I. Selecting focal species using a Delphi survey approach. Landsc Urban Plan 58:25-40

Hestmark G (2000) Temptations of the tree. Nature 408:911

Hill E, Dorfman JH, Kramer E (2010) Evaluating the impact of government landuse policies on tree canopy coverage. Land Use Policy 27:407-414

Hong SK, Song IJ, Wu JG (2007) Fengshui theory in urban landscape planning. Urban Ecosyst 10:221-237

Ignatieva M, Stewart GH, Meurk C (2010) Planning and design of ecological networks in urban areas. Landsc Ecol Eng 7:17-25

Jalas J (1955) Hemerobe und hemerochore Pflanzenarten. Ein Terminologischer Reformversuch. Acta Soc Fauna Flora Fenn 72(11):1-15

James P, Bound D (2009) Urban morphology types and open space distribution in urban core areas. Urban Ecosyst 12:417-424

James P, Tzoulas K, Adams MD, Barber A, Box J, Breuste J, Elmqvist T, Frith M, Gordon C, Greening KL, Handley J, Haworth S, Kazmierczak AE, Johnston M, Korpela K, Moretti M, Niemelä J, Pauleit S, Roe MH, Sadler JP, Thompson CW (2009) Towards an integrated understanding of green space in the European built environment. Urban For Urban Plan 8:65-75

Jenks M, Burton E, Williams K (eds) (1996) The compact city: a sustainable urban form. Spon, London

Jim CY (1988) Preservation of a large Chinese Banyan on a construction site. J Arboric 14(7):176-180

Jim CY (1989) Tree canopy cover, landuse and planning implications in urban Hong Kong. Geoforum 20:57-68

Jim CY (1993) Soil compaction as a constraint to tree growth in tropical and subtropical urban habitats. Environ Conserv 20:35-49

Jim CY (1994a) Champion trees in urban Hong Kong. Hong Kong Flora and Fauna series. Urban Council, Hong Kong

Jim CY (1994b) Evaluation and preservation of champion trees in urban Hong Kong. Arboric J 18:25-51

Jim CY (1995) Transplanting two champion specimens of mature Chinese Banyans. J Arboric 21(6):289-295

Jim CY (1997a) Roadside trees in urban Hong Kong: tree size and growth space. Arboric J 21:73-88

Jim CY (1997b) Roadside trees in urban Hong Kong: tree growth and environmental condition. Arboric J 21:89-106

Jim CY (1998a) Old stone walls as an ecological habitat for urban trees in Hong Kong. Landsc Urban Plan 42:29-43

Jim CY (1998b) Soil compaction at tree planting sites in urban Hong Kong. In: Watson GW, Neely D (eds) The landscape below ground II. International Society of Arboriculture, Champaign, pp 166178

Jim CY (1998c) Urban soil characteristics and limitations for landscape planting in Hong Kong. Landsc Urban Plan 40:235-249

Jim CY (1998d) Physical and chemical properties of a Hong Kong roadside soils in relation to urban tree growth. Urban Ecosyst 2:171-181 
Jim CY (1998e) Soil characteristics and management in an urban park in Hong Kong. Environ Manag 22:683-695

Jim CY (1999) A planning strategy to augment the diversity and biomass of roadside trees in urban Hong Kong. Landsc Urban Plan 44:13-32

Jim CY (2002) A draft urban tree ordinance for Hong Kong. Unpublished document submitted to the government of the Hong Kong Special Administrative Region on 20 April 2002, and revised on 14 December 2002, Hong Kong

Jim CY (2003a) Conservation of soils in culturally protected woodlands in rural Hong Kong. For Ecol Manag 175:339-353

Jim CY (2003b) Protection of urban trees from trenching damage in compact city environments. Cities 20:8794

Jim CY (2004a) Evaluation of heritage trees for conservation and management in Guangzhou city (China). Environ Manag 33(1):74-86

Jim CY (2004b) Spatial differentiation and landscape-ecological assessment of heritage trees in urban Guangzhou (China). Landsc Urban Plan 69:51-68

Jim CY (2005a) Monitoring the performance and decline of heritage trees in urban Hong Kong. J Environ Manage 74:161-172

Jim CY (2005b) Floristics, performance and prognosis of historical trees in the urban forest of Guangzhou city (China). Environ Monit Assess 102:285-308

Jim CY (2005c) Outstanding remnants of nature in compact cities: patterns and preservation of heritage trees in Guangzhou city (China). Geoforum 36:371-385

Jim CY (2006) Formulaic expert method to integrate evaluation and valuation of heritage trees in compact city. Environ Monit Assess 116:53-80

Jim CY (2008) Ecological design of sky woodland in compact urban Hong Kong. Greening rooftops for sustainable communities. Green Roofs for Healthy Cities, Baltimore, pp 1-15

Jim CY (2011a) Urban woodlands as distinctive and threatened nature-in-city patches. In: Douglas I, Goode D, Houck MC, Wang R (eds) The Routledge handbook of urban ecology. Routledge, New York, pp 323337

Jim CY (2011b) Holistic research agenda for sustainable management and conservation of urban woodlands. Landsc Urban Plan 100:375-379

Jim CY, Chen SS (2003) Comprehensive greenspace planning based on landscape ecology principles in compact Nanjing city, China. Landsc Urban Plan 65:95-116

Jim CY, Chen WY (2006a) Perception and attitude of residents towards urban greenspaces in Guangzhou (China). Environ Manag 38:338-349

Jim CY, Chen WY (2006b) Recreation-amenity use and contingent valuation of urban greenspaces in Guangzhou, China. Landsc Urban Plan 75:81-96

Jim CY, Chen WY (2006c) Impacts of urban environmental elements on residential housing prices in Guangzhou (China). Landsc Urban Plan 78:422-434

Jim CY, Chen WY (2007) Consumption preferences and environmental externalities: a hedonic analysis of the housing market in Guangzhou (China). Geoforum 38:414-431

Jim CY, Chen WY (2009a) Urbanization effect on floristic and landscape patterns of greenspaces. Landsc Res 34:581-598

Jim CY, Chen WY (2009b) Natural and cultural influences on spatial differentiation of species diversity in Taipei's urban forests. Appl Geogr 29:577-587

Jim CY, Chen WY (2009c) Ecosystem services and valuation of urban forests in China. Cities 26:187-194

Jim CY, Chen WY (2009d) Value of scenic views: hedonic assessment of private housing in Hong Kong. Landsc Urban Plan 91:226-234

Jim CY, Chen WY (2010) Habitat effect on vegetation ecology and occurrence on urban masonry walls. Urban For Urban Green 9:169-178

Jim CY, Chen WY (2011) Bioreceptivity of buildings for spontaneous arboreal flora in compact city environment. Urban For Urban Green 10:19-28

Jim CY, He HM (2011) Estimating heat flux transmission of vertical greenery ecosystem. Ecol Eng 37:11121122

Jim CY, Liu HT (2000) Statutory measures for the protection and enhancement of the urban forest in Guangzhou City, China. Forestry 73:311-329

Jim CY, Peng LLH (2012) Weather effect on the thermal and energy performance of an extensive tropical green roof. Urban For Urban Green 11:73-85

Jim CY, Tsang SW (2011) Ecological energetics of tropical intensive green roof. Energ Build 43:2696-2704

Johnston J (1990) Nature areas for city people. Ecology handbook 14. London Ecology Unit, London 
Jorgensen A, Tylecote M (2007) Ambivalent landscapes: wilderness in the urban interstices. Landsc Res 32:443-462

Kong F, Yin H, Nakagoshi N, Zong Y (2010) Urban green space network development for biodiversity conservation: identification based on graph theory and gravity modeling. Landsc Urban Plan 95:16-27

Kuhns LJ, Meyer PW, Patterson J (1985) Creative site preparation. Ágora 5:7-10

Lawrence HW (1988) Origins of the tree-lined boulevard. Geogr Rev 78:355-374

Lawrence HW (1993) The neoclassical origins of modern urban forests. For Conserv Hist 37:26-36

Lee JT, Thompson S (2005) Targeting sites for habitat creation: an investigation into alternative scenarios. Landsc Urban Plan 71:17-28

Lindsey P, Bassuk N (1991) Specifying soil volumes to meet the water needs of mature urban trees and tees in containers. Arboric J 17:141-149

Lo AYH, Jim CY (2012) Citizen attitude and expectation towards greenspace provision in compact urban milieu. Land Use Policy 29:577-586

Löfvenhaft K, Björn C, Ihse M (2002) Biotope patterns in urban areas: a conceptual model integrating biodiversity issues in spatial planning. Landsc Urban Plan 58:223-240

Malpezzi S (2003) Hedonic pricing models: a selective and applied review. In: O’Sullivan T, Gibb K (eds) Housing economics and public policy. Blackwell, Oxford, pp 67-89

Marcotullio PJ (2001) Asian urban sustainability in the era of globalization. Habitat Int 25:577-598

Matheny N, Clark JR (1998) Trees and development: A technical guide to preservation of trees during land development. International Society of Arboriculture, Champaign

Mattheck C, Breloer H (1994) The body language of trees. HMSO, London

Maunder M, Higgens S, Culham A (2001a) The effectiveness of botanic garden collections in supporting plant conservation: a European case study. Biodivers Conserv 10:383-401

Maunder M, Lyte B, Dransfield J, Baker W (2001b) The conservation value of botanic garden palm collections. Biol Conserv 98:259-271

Mazzotti FJ, Morgenstern CS (1997) A scientific framework for managing urban natural areas. Landsc Urban Plan 38:171-181

Millard A (2008) Semi-natural vegetation and its relationship to designed urban greenspace at the landscape scale in Leeds, UK. Landsc Ecol 23:1231-1241

Mills A, Francis T, Shandas V, Whittaker K, Graybill JK (2009) Using best available science to protect critical areas in Washington State: challenges and barriers to planners. Urban Ecosyst 12:157-175

Morell JD (1992) Competition for space in the urban infrastructure. Arboric J 18:73-75

Morgenroth J, Buchan GD (2009) Soil moisture and aeration beneath pervious and impervious pavements. Arboric Urban For 35:135-141

Müller-Perband E (1979) The modern town park in Germany. In: Laurie IC (ed) Nature in cities. John Wiley, New York, pp 297-326

National Geographic (2012) Special issue: 7 billion. Electronic app for iPad. National Geographic Society, Washington, DC

New York City (2012) Zoning tools: Streetscape improvements. Department of City Plannng, New York. http://www.nyc.gov/html/dcp/html/zone/zh ztools streetscape.shtml, accessed on 17 June 2012

Nordh H, Hartig T, Hagerhall CM, Fry G (2009) Components of small urban parks that predict the possibility for restoration. Urban For Urban Green 8:225-235

Nowak DJ, Dwyer JF (2000) Understanding the benefits and costs of urban forest ecosystems. In: Kuser JE (ed) Handbook of urban and community forestry in the Northeast. Kluwer, New York, pp 11-25

Olembo RJ, de Rham P (1987) Urban forestry in two different worlds. Unasylva 39:26-35

Ormsby AA (2011) The impacts of global and national policy on the management and conservation of sacred groves of India. Hum Ecol 39:783-793

Pennington DN, Hansel JR, Gorchov DL (2010) Urbanization and riparian forest woody communities: diversity, composition, and structure within a metropolitan landscape. Biol Conserv 143:182-194

Perry TO (1982) The ecology of tree roots and the practical significance thereof. J Arboric 8:197-211

Perry TO (1994) Size, management and design of tree planting sites. In: Watson GW, Neely D (eds) The landscape below ground. International Society of Arboriculture, Savoy, pp 3-15

Petit J, Bassert DL, Kollin C (1995) Building greener neighborhoods: Trees as part of the plan. American Forestry Association, Washington, DC

Portland City (2012) Street tree lists: Planting the right tree in the right place. Portland Parks and Recreation, Portland, OR. http://www.portlandonline.com/parks/, accessed on 17 June 2012

Powell MA (1992) Pruning trees, flushcuts and wound dressings. North Carolina Cooperative Extension Service, North Carolina State University, Greensboro

Qureshi S, Breuste JH (2010) Prospects of biodiversity in the mega city Karachi, Pakistan: potentials, constraints and implications. In: Müller N, Werner P, Kelcey J (eds) Urban biodiversity and design: Implementing the convention on biological diversity in towns and cities. Wiley-Blackwell, Oxford, pp 497-517 
Qureshi S, Kazmi SJH, Breuste JH (2010) Ecological disturbances due to high cutback in the green infrastructure of Karachi: analyses of public perception about associated health problems. Urban For Urban Green 9:187-198

Randall CE, Clepper H (1977) Famous and historic trees. American Forestry Association, Washington, DC Scalenghe R, Marsan FA (2009) Anthropogenic sealing of soils in urban areas. Landsc Urban Plan 90:1-10

Schadek U, Strauss B, Biedermann R, Kleyer M (2009) Plant species richness, vegetation structure and soil resources of urban brownfield sites linked to successional age. Urban Ecosyst 12:115-126

Smale MC, Gardner RO (1999) Survival of Mount Eden Bush, an urban forest remnant in Auckland, New Zealand. Pac Conserv Biol 5:83-95

Starbuck CJ (2007) Pruning ornamental shrubs. University of Missouri Extension, Columbia

Steiner F (2011) Landscape ecological urbanism: origins and trajectories. Landsc Urban Plan 100:333-337

Strohbach MW, Haase D (2012) Above-ground carbon storage by urban trees in Leipzig, Germany: analysis of patterns in a European city. Landsc Urban Plan 104:95-104

Sukopp H (1972) Wandel von Flora und Vegetation in Mitteleuropa unter dem Einfluss des Menschen. Ber Landwirtsch 50:112-130

Takahashi T, Amano Y, Kuchimura K, Kobayashi T (2008) Carbon content of soil in urban parks in Tokyo, Japan. Landsc Ecol Eng 4:139-142

Tartaglia-Kershaw M (1982) The recreational and aesthetic significance of urban woodland. Landsc Res 7:22-25

Thompson CW (2002) Urban open space in the 21st century. Landsc Urban Plan 59:59-72

Tian Y, Jim CY (2011) Factors influencing the spatial pattern of sky gardens in the compact city of Hong Kong. Landsc Urban Plan 101:299-309

Tian Y, Jim CY, Tao Y, Shi T (2011) Landscape ecological assessment of green space fragmentation in Hong Kong. Urban For Urban Green 10:79-86

Towne MA (1998) Open space conservation in urban environments: lessons from Thousand Oaks, California. Urban Ecosyst 2:85-101

Troy AR, Grove JM, O'Neil-Dunne JPM, Pickett STA, Cadenasso ML (2007) Predicting opportunities for greening and patterns of vegetation on private urban lands. Environ Manag 40:394-412

Tzoulas K, James P (2010) Peoples' use of, and concerns about, green space networks: a case study of Birchwood, Warrington New Town, UK. Urban For Urban Green 9:121-128

United Nations Population Fund (2012) State of the world population 2011: people and possibilities in a world of 7 billion. Information and External Relations Division of UNFPA, United Nations Population Fund

Van Der Windt HJ, Swart JAA (2008) Ecological corridors, connecting science and politics: the case of the Green River in the Netherlands. J Appl Ecol 45:124-132

Watson GW, Himelick EB (1997) Principles and practice of planting trees and shrubs. International Society of Arboriculture, Savoy

Watson GW, Himelick EB (2005) Tree planting. International Society of Arboriculture, Savoy

Watson GW, Neely D (eds) (1995) Trees and building sites. International Society of Arboriculture, Champaign

Williams NSG, McDonnell MJ, Seager EJ (2005) Factors influencing the loss of an endangered ecosystem in an urbanising landscape: a case study of native grasslands from Melbourne Australia. Landsc Urban Plan 71:35-49

World Bank (2012) How we classify countries. http://data.worldbank.org/about/country-classifications, accessed on 17 June 2012

Young RF (2010) Managing municipal green space for ecosystem services. Urban For Urban Green 9:313-321 